\title{
Is Ultra-Broadband Enough? The Relationship between High-Speed Internet and Entrepreneurship in Brandenburg
}

\author{
Kirill Sarachuk ${ }^{*}$, Magdalena Mißler-Behr ${ }^{1}$ \\ ${ }^{1}$ Brandenburg University of Technology, Erich-Weinert-Straße 1, 03046 Cottbus, Germany
}

\begin{abstract}
Recent improvements in broadband infrastructure in Europe have introduced augmented possibilities for both businesses and individuals. As expected, the provision of high-speed internet connections for European users will be an important step towards Industry 4.0 as well as a better entrepreneurial milieu. Still, though scientific literature is replete with examples of how modern communication technologies boost productivity and economic performance, not much research indicates how broadband technologies may bolster entrepreneurship, especially at a very detailed, municipal level. The aim of this study was to find out whether high-speed broadband provision had any effect on higher firm entry rates in Brandenburg, Germany. This region was chosen because of its favorable position in the vicinity of the capital state, Berlin. We carried out an ordinary less square estimated regression analysis using a dataset built for 417 municipalities. The results show that ultra-broadband provision had no significant impact on well-performing municipalities and those located close to Berlin, with no impact in the general model, and also had a negative correlation in underperforming and peripheral areas (significant at a $5 \%$ level). This leads to the conclusion that advanced broadband infrastructure does not automatically translate into higher firm entry rates; there is no such urgency in the need for speed, as it might appear at first glance.
\end{abstract}

Keywords: Broadband; Entrepreneurship; Germany; ICT

\section{Introduction}

Level of entrepreneurial activity, traditionally represented by firm formation rate, is considered a main indicator of both regional and national economic development (Noseleit, 2013). Since higher firm entry rates create the appearance of a competitive milieu, a positive net entry ratio represents a sign of further development, along with a reduction ot the possibility of lock-in situations (David, 2001).

Clearly firms do not show up from nowhere, but rather local infrastructure is a fundamental prerequisite in attracting potential founders to the region (Haynes and Nijkamp, 2006). Recent scientific literature mentions a wide range of factors that are conducive to increased market entry, from physical infrastructure to the presence of highskilled labor. One more factor - digital infrastructure - seems to be of particular importance in recent years: modern information and communication technologies (ICTs) introduced a paradigm-shift in entrepreneurship over the past decades by blurring both time and space boundaries.

More countries are recognizing that ICTs may bolster both economic development and entrepreneurship, paving the way to tremendous transformations in broadband provision 
globally (OECD, 2012). Some areas seems to be more advanced in their digital strategies, such as the European Union with its comprehensive policy called the Digital Agenda for Europe (European Commission, 2010), which proposes bringing high-speed internet to European households and encourages the promotion of next-generation access networks (NGAN). It is expected that advanced digital infrastructure will be a fundamental step in the transition towards Industry 4.0 and will promote entrepreneurship quickly, starting at a regional level.

The latter notion, however, represents a common misconception that developments in broadband provision lead to positive transformations in entrepreneurial patterns. Truly, businesses require better connections, for instance, in terms of data exchange or ensuring the smooth functioning of web-based applications. However, broadband cannot guarantee higher net entry rates or significant advantages for existing and new firms. Even though scholars have observed a positive impact of ICTs on entrepreneurship (McCoy et al., 2018) and the innovative capabilities of firms (Xu et al., 2019), the rule the faster, the better does not necessarily work in the context of economic benefits (Bai, 2017).

Still, while most scholars analyzed the effects of ICTs' development at aggregated levels (cross-regional or [multi]national), very few studies try to dive a bit deeper. Our paper is not the first to explore the relationship between broadband and firm entry rates in Germany (Audretsch et al., 2010), but it is among the first ones searching for such effects at a very detailed level (municipalities). Older papers on the municipality level (Fabritz, 2013) date back to outdated internet technologies such as DSL.

The Brandenburg region was chosen for our study, to a great extent because of its geographical features: first, it is located in the eastern part of Germany, where a partial inheritance of socialistic patterns (particularly in terms of entrepreneurship) is still present; second, Brandenburg is adjacent to Berlin, so new and incumbent firms may benefit from most of the advantages of the German capital (Regionaldatenbank Deutschland, 2018). Though the role of broadband internet in Brandenburg may seem questionable given that the vast majority of its territory is rural, with a relatively small number of big cities, Kim and Orazem (2016) found that such an adjacency to a metropolitan area with good high-speed internet availability can be conductive to potential entrants. In our research, we used data from Breitbandatlas Deutschland (Broadband Map for Germany) as well as officially distributed data of the Federal Statistical Office of Germany from Regionaldatenbank (Regional Data Bank) and Unternehmensregister (Registry of Companies) for 417 Brandenburg municipalities. An ordinary less square (OLS) estimated regression was chosen as the scientific method for our empirical analysis.

Our paper unfolds as follows: Chapter 2 provides a brief background on the existing literature. Then Chapter 3 presents an overview of the EU Digital Agenda and its fulfillment in Germany, with special consideration of Brandenburg. Chapter 4 describes existing entrepreneurial patterns in Germany, first from a nationwide scope and then focusing on our particular case. The data and results of our regression analysis follow in Chapters 5 and 6 , respectively, and finally Chapter 7 concludes our paper with a short summary.

\section{Literature Background}

The spurring effect of ICTs is well documented in the scientific literature. Above all, there is a strong belief that telecommunications contribute to overall economic growth and business activities. Such a positive effect was already observed in the case of telephony (Hardy, 1980), both for developing and developed countries. Further studies also revealed a link between the development of telecommunications and productivity gains (Cronin et al., 1991; Greenstein and Spiller, 1995). More precisely, nearly a third of economic growth 
in more than twenty OECD countries in 1970 s and 1980 s can be attributed to telecommunication infrastructure (Roller and Waverman, 2001).

The introduction of dial-up and later broadband internet connections did not change the general effect of telecommunication much: newer ICTs also serve as catalysts for business activity (including small business, see Qosasi et al., 2019) and productivity gains (OECD, 2003; Hagén et al., 2008), just with a small notion that the impact of broadband connections is much stronger (Grimes et al., 2012). Still, some researchers could not confirm with a high level of confidence a pronounced enabling effect of ICTs (Haller and Lyons, 2015) because of the related factors of the presence of high-skilled employees (Mack and Faggian, 2013; Akerman et al., 2015) and larger investments into skills and strategic transformation (Colombo et al., 2013). Further studies connect ICTs and economic performance with innovative activities (Suryanegara et al, 2019; Xu et al., 2019), improvements in technologies and infrastructure (Koutroumpis, 2009), and higher employment rates and economic gains (Jorgenson and Motohashi, 2005; Lehr et al., 2006).

Although numerous studies recognize the importance of ICTs in creating a favorable entrepreneurial milieu, it is quite stunning that very few scholars have tried to link their impact to entrepreneurship itself (Sarachuk and Missler-Behr, 2020). In the most up-todate study, McCoy et al. (2018) observed the positive impact DSL and fiber broadband connections had on high-tech business sectors, with the latter being more beneficial. There was some evidence that ICTs may serve as substitutes for handshake interaction (Mack, 2014), especially in peripheral areas (ICTs may serve as an enabling power in stagnating and lagging regions, see Fornefeld et al., 2008), despite the fact that some findings associated the positive effects produced by broadband provision with core regions (Capasso et al., 2016), namely metropolitan areas.

A small cohort of scholars has tried to link ICTs with business location patterns. Parajuli and Haynes (2017) observed the spatial variety effects of broadband provision onto new business formations, while Kim and Orazem (2016) found a positive effect of broadband availability on locating new firms in rural areas, amplified in cases of high population and adjacency to a metropolitan area. Contrast to that, Mack and Grubestic (2009) failed to connect changes in firm location with improvements in broadband provision in Ohio, USA, albeit at a firm level analysis firm size and industry were observed as significant features. Later research on the same area revealed that agricultural and rural establishments are prone to be located in areas with better broadband connections (Mack, 2014).

\section{Broadband Development in Europe and Germany}

Over the last few years, the structure and quality of telecommunications have experienced numerous radical changes. Europe's digital transformation is largely associated with the emergence of Digital Agenda for Europe, a ten-year plan underlining the "importance of broadband deployment to promote social inclusion and competitiveness" (European Commission, 2010, p. 19). The initiative proposed that all European citizens get basic broadband access by the end of 2013, but also that internet speed across Europe must reach a minimum threshold of $30 \mathrm{Mbps}$ by 2020. Besides that, the EU Digital Agenda sets a target to promote NGAN and make them available to at least half of European households ${ }^{1}$

\footnotetext{
${ }^{1}$ A further update in 2016 sets three additional goals for 2025 (European Commission, 2020): (1) stable 5Gwireless coverage for cities and major transportation lines; (2) minimum download speed for European households of $100 \mathrm{Mbps}$ and the promotion of $1 \mathrm{Gbps}$, while the latter speed (3) must be granted to "all schools, transport hubs and main providers of public services and digitally intensive enterprises."
} 
A question, however, arises of if all EU countries are capable of developing their own digital infrastructure in order to achieve a spurring effect on entrepreneurship. Generally, the answer is negative, in so far as some countries have failed to meet even the first target for basic broadband access (like Italy, see Matteucci, 2014). As Vassiliou and McAleese (2014) mention, European governmental institutions often miss straightforward policies and targets; as a result, organic technological development is utterly impossible. ${ }^{2}$

Germany, being a flagship European economy, has performed adequately with respect to the implementation of Digital Agenda goals, thanks to better overall digital skills and technology acceptance. Still, Germany's development of its own digital infrastructure is not that much better than the EU average, as demonstrated by the latest DESI Report (European Commission, 2019b): for instance, urbanized areas deserve more attention in terms of broadband infrastructure (before all NGAN) as they are potentially better places for new businesses. Recent reports from BMVI $(2014,2018)$ clearly show that even the first objective has not been accomplished so far, and the successful realization of the second part of the Digital Agenda by the end of 2020 is highly questionable.

Some pronounced differences may be observed between former western and eastern German states. Just three city-states - Berlin, Hamburg and Bremen - benefit from the best high-speed coverage, close to a hundred percent. In contrast to the west, the eastern part of Germany lags in terms of fast broadband coverage. Brandenburg, specifically, does not have the worst coverage: basic broadband provision quality (16 Mbps and $30 \mathrm{Mbps}$ ), at least, is almost indistinguishable from western states. However, together with SaxonyAnhalt and Thuringia, Brandenburg has the most underdeveloped NGAN infrastructure, especially for connections at speed of $100 \mathrm{Mbps}$ or better. It is fair to say that Brandenburg has far fewer urbanized areas and big cities, but that does not justify weaker broadband coverage given the presence of huge rural areas in the western part of Germany as well. It is generally true that Brandenburg municipalities located closer to Berlin benefit from better connections (see Figure 1), and the periphery remains covered primarily with basic technologies (with the rare exceptions of Cottbus, Pirow or Welzow, see (BMVI, 2019a) for more information).

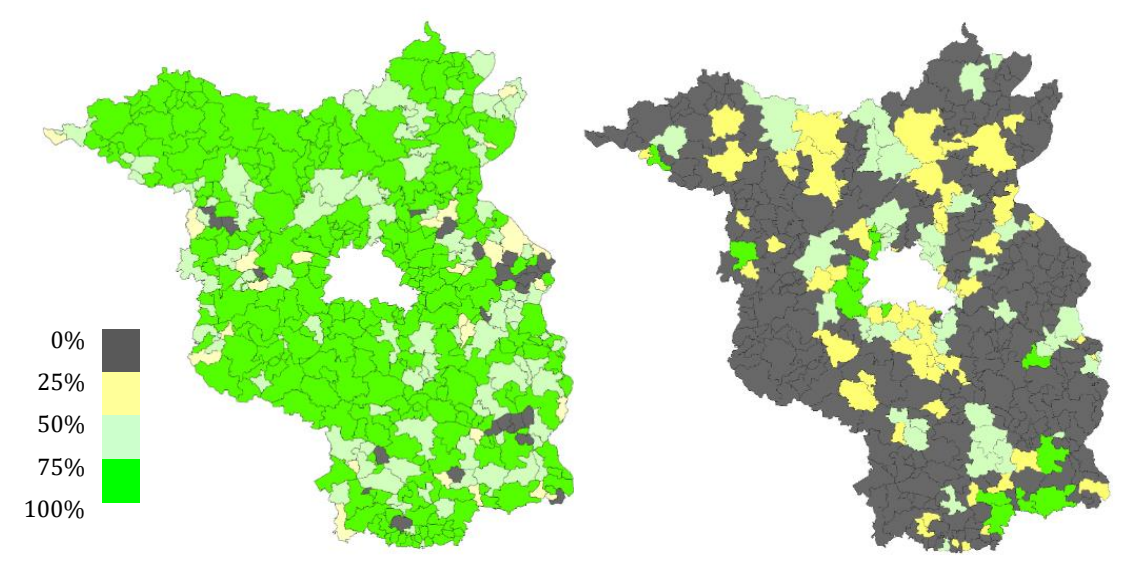

Figure 1 Broadband coverage map for $\geq 30 \mathrm{Mbps}$ (left) and $\geq 100 \mathrm{Mbps}$ (right) in 2018 Source: Breitbandatlas Deutschland

\footnotetext{
${ }^{2}$ As in 2018, broadband coverage for EU citizens was nearly $97 \%$ and $83 \%$ for faster broadband, while in just 10 EU Member States were more than 99\% of households covered by high-speed Internet connections. Additionally, rural areas seem to be underdeveloped across the whole of Europe, in contrast to urbanized areas (European Commission, 2019a). Malta was the first country to report the accomplishment of NGAN coverage in 2017 (IHS Markit, 2018), followed by the Netherlands and Belgium, while Lithuania, Poland, Romania and Slovakia are falling short of even the first milestone.
} 


\section{Entrepreneurial Milieu in Germany: A Short Overview}

Germany is often named as the driver of the European economy, but, despite good overall economic performance, its entrepreneurial milieu is not the best in Europe, as the level of self-employment has remained rather weak in past decades (OECD, 2018). One of the major reasons for this is the presence of pronounced differences between former western and eastern parts of the country with respect to the entrepreneurial behavior and innovative activity.

The core industries of East Germany are those with lower share of high-skilled employees (Ragnitz, 2007) - in contrast, the former west Germany is full of labor- and knowledge intensive industries. Poor networking, as reported by Global Entrepreneurship Index (Ács et al., 2018) may explain why eastern Germany still lacks R\&D clusters and demonstrates lower levels of regional competitiveness (Kosfeld and Mitze, 2020). Overall, the largest impediment to German entrepreneurship is an incredibly low entrepreneurial spirit compared to other developed economies, which is closely connected to the lack of entrepreneurial education at universities (Bittorf, 2013). Last but not least in the problem of social acceptance of start-ups and their success: an entrepreneurial failure in Germany is rather treated as a reputational loss (Wyrwich et al., 2016) whilst American culture follows a no pain, no gain principle, thus encouraging entrepreneurs to carry on in the face of setbacks. Furthermore, there is a strong belief that people with higher level of experience and gathered knowledge, aged fifty or more, are more likely to open a successful business (Sternberg and Bloh, 2017), rather than young individuals.

Since the economic recession of 2008-2009, the total number of firms in Germany has increased by nearly $1.3 \%$ (as of 2018), but positive net entry rates are primarily observed in western Germany (with Rheinland-Pfalz and Saarland as exceptions). It is also not surprising that the capital Berlin is far ahead with a more than $7 \%$-increase in business population from 2015 to 2018. At the same time, eastern Germany is constantly shedding active businesses. Brandenburg, however, does not seem to be a lagging region, but it is stagnating. Still, as is the case with broadband, higher entry rates can be observed for municipalities located closer to Berlin (see Figure 2), while entities on the periphery lose entrepreneurial activity from year to year. A substantial loss is observed mainly in the manufacturing sector (annual net entry rate is -566 firms), while the service sector $(+272)$, knowledge intensive business services and ICT $(+231)$ are performing much better.

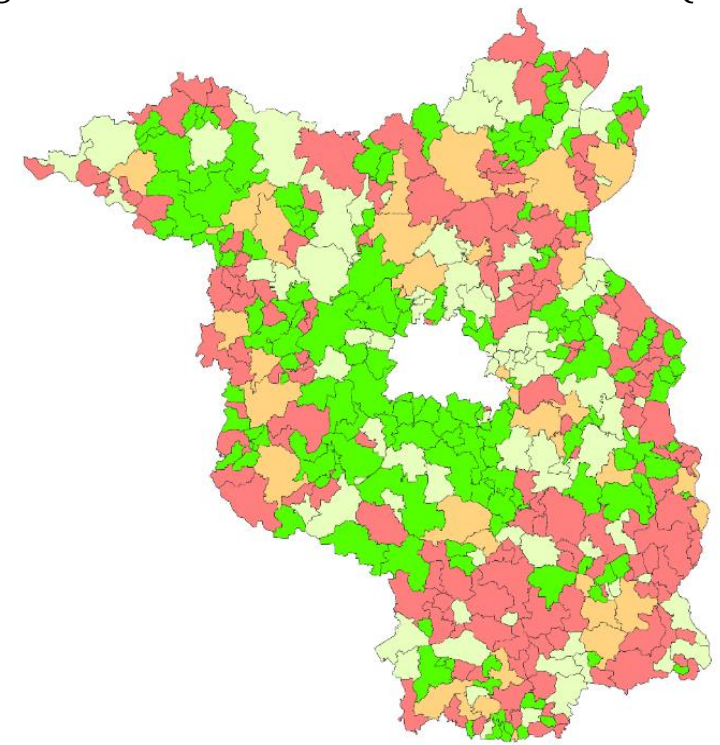

$+2.5 \%$ or better

$0 \%$ to $+2.5 \%$

$0 \%$ to $-2.5 \%$

$-2.5 \%$ or worse

Figure 2 Changes in firm population between 2015 and 2018, Brandenburg municipalities Source: Regionaldatenbank Deutschland, 2018 


\section{Data and Methodology}

As we have stated, the aim of this paper is to prove whether the recent improvements in broadband infrastructure in Brandenburg had any effect on entrepreneurial activity. As we know from Chapter 3, basic broadband provision (at $\geq 30 \mathrm{Mbps}$ ) does not differ much between Brandenburg municipalities, while some pronounced differences may be found for augmented broadband technology availability as well as recent changes in firm population. Therefore, we decided to look at whether better coverage with ultra-broadband internet at speeds exceeding $100 \mathrm{Mbps}$ has any plausible influence on firm formation in Brandenburg.

Besides digital infrastructure, firm formation depends on a wide range of factors, like business formation size (Fritsch and Falck, 2007), social diversity (Lee et al., 2004), and presence of high-skilled employees (Mack and Faggian, 2013). Some other aspects such as proximity to universities, which is especially important for knowledge-intensive businesses (Audretsch et al., 2004; Mack, 2014), physical infrastructure (Holl, 2004; Percoco, 2016) and industry type (Mack and Grubesic, 2009) could also be taken into consideration.

We were, however, unable to include all the aforementioned control variables into our regression model due to a very limited amount of data available at the municipality level. For instance, higher GDP and income per capita mean greater household wealth and, as suggested, that may translate into new business formations (Parajuli and Haynes, 2017). These data, however, were not available so instead we used the tax revenue per capita of municipalities, which is connected to employment income and household wealth. We also included population data, namely density and size of the economically active population (aged 15-65), as far as they positively affect new firm formations (see Armington and Ács, 2002). In addition, unemployment may necessitate entrepreneurship, so we included that parameter as well. Culturally diverse areas may be more attractive to entrepreneurs (Hart et al., 2011), so we included the amount of people with a migratory background into our model. Physical infrastructure, such as proximity to the nearest airport and road and railroad accessibility, is often described as a driver of entrepreneurship (Percoco, 2016) and was not overlooked. The final variable is proximity to universities, as they disseminate knowledge (knowledge spillovers) and provoke higher firm entry rates.

Taking into account that our data were retrieved for 2018 only, and we are searching for a relationship between firm entry rate and ultra-broadband internet, we use the classic OLS estimated regression method in our analysis, as was done in studies by Kolko (2012) and Fabritz (2013). The equation we developed is as follows:

$$
F E_{2018}=\alpha+\beta \times U B B_{2018}+\gamma \times \text { Controls }_{2018}+\varepsilon,
$$

where (a) $F E_{2018}$ is our dependent variable, firm entries in 2018, gathered from Registry of Companies Brandenburg; (b) UBB2018 stands for ultra-broadband coverage, our explaining variable, derived from Broadband Atlas for Germany; and (c) Controls2018 is a matrix that includes demographic, physical infrastructure, and financial performance data gathered from Regional Database Germany or calculated on our own. The final dataset includes data for 417 municipalities in Brandenburg (see Table 1).

We decided not to look solely at the entire sample (Model 1). As some municipalities were more attractive to businesses due to better economic performance, we analyzed municipalities with positive average net entry rates from 2015 to 2017 (Model 2) separate from those with negative net entry rates (Model 3). Entities located closer to Berlin may benefit from better digital infrastructure and usually have higher entry rates, so we analyzed them (within $30 \mathrm{~km}$ from the state border of Berlin, Model 4) apart from municipalities located in periphery and semi-periphery of Brandenburg (Model 5). 
Table 1 Description of variables (number of observations/municipalities $=417$ )

\begin{tabular}{|c|c|c|c|c|c|c|}
\hline Variable & Description & Mean & St. Dev. & Min & Max & Source \\
\hline $\begin{array}{l}\text { Firm Entries } \\
\text { in } 2018\end{array}$ & $\begin{array}{l}\text { Number of new firms } \\
\text { (business formations) }\end{array}$ & 41.369 & 101.082 & 0 & 1480 & $\begin{array}{l}\text { Amt für Statistik } \\
\text { Berlin-Brandenburg } \\
\text { (2018) }\end{array}$ \\
\hline $\begin{array}{l}\text { Ultra- } \\
\text { Broadband } \\
\text { Coverage }\end{array}$ & $\begin{array}{l}\text { High-speed broadband coverage } \\
\text { at } 100 \mathrm{Mbps} \text { or more, in percent }\end{array}$ & 17.868 & 24.038 & 0 & 93 & $\begin{array}{l}\text { Breitbandatlas } \\
\text { Deutschland } \\
\text { (BMVI, 2019b) }\end{array}$ \\
\hline Density & $\begin{array}{l}\text { Population density, } \\
\text { in hundreds per sqkm }\end{array}$ & 1.185 & 2.603 & 0.076 & 26.523 & \multirow{4}{*}{$\begin{array}{l}\text { Regionaldatenbank } \\
\text { Deutschland (2018) }\end{array}$} \\
\hline $\begin{array}{l}\text { Population } \\
15-65\end{array}$ & $\begin{array}{l}\text { Economically active population } \\
\text { aged } 15-65 \text {, in hundreds }\end{array}$ & 37.799 & 81.179 & 2.280 & 1148.86 & \\
\hline Unemployed & $\begin{array}{l}\text { Unemployed people, } \\
\text { per hundred inhabitants }\end{array}$ & 2.325 & 2.191 & 0.123 & 38.505 & \\
\hline Migrants & $\begin{array}{l}\text { People with migration back- } \\
\text { ground, per hundred inhabitants }\end{array}$ & 2.030 & 3.322 & 0 & 39.958 & \\
\hline $\begin{array}{l}\text { Proximity to } \\
\text { University }\end{array}$ & $\begin{array}{l}\text { Distance to the nearest university, } \\
\text { in km }\end{array}$ & 32.014 & 16.190 & 0 & 82.100 & \multirow{2}{*}{$\begin{array}{l}\text { Calculated with help } \\
\text { of Google Maps }\end{array}$} \\
\hline $\begin{array}{l}\text { Proximity to } \\
\text { Airport }\end{array}$ & $\begin{array}{l}\text { Distance to the nearest airport, } \\
\text { in } \mathrm{km}\end{array}$ & 74.433 & 34.188 & 1 & 162 & \\
\hline $\begin{array}{l}\text { Roads \& } \\
\text { Railroads }\end{array}$ & $\begin{array}{l}\text { Total density of roads and } \\
\text { railroads, in sqkm }\end{array}$ & 2.487 & 2.313 & 0.220 & 13.480 & \multirow{2}{*}{$\begin{array}{l}\text { Regionaldatenbank } \\
\text { Deutschland (2018) }\end{array}$} \\
\hline $\begin{array}{l}\text { Real Tax } \\
\text { Revenue }\end{array}$ & $\begin{array}{l}\text { Real tax revenues, calculated as } \\
\text { thousands of Euros per capita }\end{array}$ & 0.843 & 1.085 & 0.078 & 16.856 & \\
\hline
\end{tabular}

\section{Results and Discussion}

Results of our regression analysis (OLS estimated) are presented in Table 2. In all models, the economically active population is strongly and positively associated with firm formations, which is consistent with the existing findings. Greater unemployment is statistically significant in the general model, but also in peripheral municipalities and those with negative entry rates in past periods. This could explain the presence of necessity entrepreneurship in the underperforming and peripheral areas where unemployed people see no other opportunity than to set up their own firm. In contrast, the presence of people with a migratory background is significantly and positively associated with firm formation in municipalities located closer to Berlin or with better firm dynamics, though the significance is weak. There are two possible explanations: first, migrants in Germany try to settle in bigger cities or at least closer to them in order to better integrate into society; second, migrants pursue university degrees in large numbers and then tend to stay in urbanized areas. Population density does not seem to be important, except in lagging and peripheral areas.

Proximity to a university, surprisingly, does not appear to be significant in any way in all of the models. This contradicts existing findings (Audretsch et al., 2004), however, as Mack and Faggian (2013) mention, skilled occupations matter, not the distance to the university itself (even if knowledge spillovers are present). Unfortunately, the data for highskilled workers were not available for municipalities, so we cannot test that too. Physical infrastructure is generally important, while proximity to an airport is also important for underperforming municipalities. A negative impact of distance to an airport is clear (firms tend to locate closer to big cities with international air hubs), while the negative effect of the density of roads and railways seems a bit contradictive. We interpret that in this way: the higher the density of transportation arteries is in the municipality, the higher the chance of competition, which may be crucial for the Brandenburg periphery. Financial performance is general positively and strongly significant, showing that richer areas attract 
more businesses, but particularly in municipalities with higher net entry rates in previous periods (success-breeds-success effect) and those located closer to Berlin.

Table 2 Results of regression analysis (OLS estimated)

\begin{tabular}{|c|c|c|c|c|c|}
\hline DV: Firm Entries (2018) & $\begin{array}{c}(1) \\
\text { General }\end{array}$ & $\begin{array}{c}(2) \\
\text { NE } 15-17>0\end{array}$ & $\begin{array}{c}(3) \\
\text { NE } 15-17<0 \\
\end{array}$ & $\begin{array}{c}(4) \\
\text { Berlin } 30 \mathrm{Km} \\
\end{array}$ & $\begin{array}{c}5) \\
\text { Periphery }\end{array}$ \\
\hline $\begin{array}{l}\text { Ultra-Broadband Coverage } \\
(\%)\end{array}$ & $\begin{array}{l}-0.0856 \\
{[0.0768]}\end{array}$ & $\begin{array}{c}0.196 \\
{[0.186]}\end{array}$ & $\begin{array}{c}-0.103 * * \\
{[0.0471]}\end{array}$ & $\begin{array}{c}0.151 \\
{[0.229]}\end{array}$ & $\begin{array}{c}-0.0801^{* *} \\
{[0.0362]}\end{array}$ \\
\hline $\begin{array}{l}\text { Density } \\
\text { (hundreds per sqkm) }\end{array}$ & $\begin{array}{l}1.0320 \\
{[0.722]}\end{array}$ & $\begin{array}{c}1.602 \\
{[1.607]}\end{array}$ & $\begin{array}{l}0.978^{* *} \\
{[0.0243]}\end{array}$ & $\begin{array}{c}0.484 \\
{[1.515]}\end{array}$ & $\begin{array}{l}0.865 * \\
{[0.519]}\end{array}$ \\
\hline $\begin{array}{l}\text { Population 15-65 } \\
\text { (hundreds) }\end{array}$ & $\begin{array}{c}1.187^{* * *} \\
{[0.0273]}\end{array}$ & $\begin{array}{l}1.230^{* * *} \\
{[0.0451]}\end{array}$ & $\begin{array}{l}0.960^{* * *} \\
{[0.0243]}\end{array}$ & $\begin{array}{l}1.220^{* * *} \\
{[0.0560]}\end{array}$ & $\begin{array}{c}0.885^{* * *} \\
{[0.0206]}\end{array}$ \\
\hline $\begin{array}{l}\text { Unemployed } \\
\text { (per hundred inhabitants) }\end{array}$ & $\begin{array}{c}3.212 * * * \\
{[0.778]}\end{array}$ & $\begin{array}{l}0.0305 \\
{[2.350]}\end{array}$ & $\begin{array}{c}4.126^{* * *} \\
{[0.462]}\end{array}$ & $\begin{array}{l}-0,571 \\
{[2.558]}\end{array}$ & $\begin{array}{l}1.285 * \\
{[0.534]}\end{array}$ \\
\hline $\begin{array}{l}\text { Migrants } \\
\text { (per hundred inhabitants) }\end{array}$ & $\begin{array}{c}0.410 \\
{[0.510]}\end{array}$ & $\begin{array}{l}2.162^{*} \\
{[1.178]}\end{array}$ & $\begin{array}{l}-0.228 \\
{[0.320]}\end{array}$ & $\begin{array}{c}5.939 * * \\
{[2.800]}\end{array}$ & $\begin{array}{l}-0.299 \\
{[0.208]}\end{array}$ \\
\hline $\begin{array}{l}\text { Proximity to University } \\
(\mathrm{km})\end{array}$ & $\begin{array}{c}0.166 \\
{[0.106]}\end{array}$ & $\begin{array}{l}0.0519 \\
{[0.214]}\end{array}$ & $\begin{array}{c}0.0802 \\
{[0.0717]}\end{array}$ & $\begin{array}{c}0.260 \\
{[0.442]}\end{array}$ & $\begin{array}{l}0.00269 \\
{[0.0449]}\end{array}$ \\
\hline $\begin{array}{l}\text { Proximity to Airport } \\
(\mathrm{km})\end{array}$ & $\begin{array}{l}-0.213 * * * \\
{[0.0531]}\end{array}$ & $\begin{array}{l}0.0180 \\
{[0.110]}\end{array}$ & $\begin{array}{c}-0.218 * * * \\
{[0.0364]}\end{array}$ & $\begin{array}{l}-0.219 \\
{[0.355]}\end{array}$ & $\begin{array}{l}-0.00767 \\
{[0.0253]}\end{array}$ \\
\hline $\begin{array}{l}\text { Roads \& Railroads } \\
(\mathrm{sqkm})\end{array}$ & $\begin{array}{c}-1.733^{*} \\
{[0.884]}\end{array}$ & $\begin{array}{c}1.096 \\
{[1.905]}\end{array}$ & $\begin{array}{l}0.0640 \\
{[0.613]}\end{array}$ & $\begin{array}{c}0.511 \\
{[2.634]}\end{array}$ & $\begin{array}{l}0.0925 \\
{[0.441]}\end{array}$ \\
\hline $\begin{array}{l}\text { Real Tax Revenue } \\
\text { (thsd. EUR per capita) }\end{array}$ & $\begin{array}{c}9.023 * * * \\
{[1.405]}\end{array}$ & $\begin{array}{c}8.738^{* * *} \\
{[1.891]}\end{array}$ & $\begin{array}{c}1.605 \\
{[3.001]}\end{array}$ & $\begin{array}{c}9.279^{* * *} \\
{[2.481]}\end{array}$ & $\begin{array}{c}0.842 \\
{[1.316]}\end{array}$ \\
\hline Constant & $\begin{array}{c}-4.230 \\
{[5.217]} \\
\end{array}$ & $\begin{array}{c}-22.35^{* *} \\
{[10.79]} \\
\end{array}$ & $\begin{array}{c}4.001 \\
{[3.991]} \\
\end{array}$ & $\begin{array}{l}-22.30 \\
{[21.28]} \\
\end{array}$ & $\begin{array}{l}-3.611 \\
{[2.608]}\end{array}$ \\
\hline $\begin{array}{l}\text { Observations } \\
\text { R-squared } \\
\text { Adjusted R-squared }\end{array}$ & $\begin{array}{c}417 \\
0.912 \\
0.910\end{array}$ & $\begin{array}{c}165 \\
0.929 \\
0.925\end{array}$ & $\begin{array}{c}252 \\
0.943 \\
0.941\end{array}$ & $\begin{array}{c}\mathbf{1 1 0} \\
0.927 \\
0.921\end{array}$ & $\begin{array}{c}307 \\
0.937 \\
0.935\end{array}$ \\
\hline
\end{tabular}

Standard errors in brackets. ${ }^{*}$ p: $0.1^{* *}$ p: $0.05^{* * *}$ p: 0.01

The ultra-broadband variable obtained some interesting results. The provision of highspeed internet does not seem to be statistically significant in the general model and in wellperforming or Berlin-adjacent municipalities. In contrast to that, in underperforming and peripheral areas we observed a significance but, surprisingly, a negative one. That may seem stunning given the evidence of the spurring effect of broadband for lagging regions that has been documented so far (Fornefeld et al., 2008), but broadband provision does not automatically guarantee its adoption or active exploitation (Mack, 2014). Moreover, ultrahigh-speed broadband may have a limited effect, just on particular applications, as Kolko (2010) observed in the transition from dial-up internet to modern technologies that was mostly relevant to online music services and online shopping. Hence, though higher up- and download speeds may seem more attractive for both households and businesses, they are not essential for productivity (Mack and Faggian, 2013), innovative activity (Xu et al., 2019) or, as in our case, firm creation.

\section{Conclusions}

The aim of this paper was to evaluate the impact of ultra-broadband provision on firm creation at a municipal level in Brandenburg, Germany. While the existing scientific literature shows high-speed internet provision to be a key factor in economic success, we were unable to confirm the same in our case. We did not find any statistical significance for ultra-broadband provision in better-performing municipalities and those located in the vicinity of the capital, Berlin, or in the general model. In contrast to that, in underperforming and peripheral areas the relationship was significant and negative, which does not allow us to state that ultra-broadband is an important prerequisite for better regional entrepreneurship. Hence, digital policies may have to incorporate additional aspects (such as the improvement of technological skills or encouragement of entrepreneurial spirit), and 
not solely focus on the development of digital infrastructure: even though modern technologies might seem fascinating, there is no urgency in the need for speed over a certain broadband rate.

While we observed some interesting outcomes for the broadband variable, the results for the rest of the parameters stay remained in line with the existing literature. Still, some problems were excluded from this paper due to the scarcity of data on the municipal level. For instance, we were unable to test the effects of broadband provision along with the presence of technological skills in a region on productivity, innovativeness of firms, and possible location patterns. Though this paper is a rare example of a study trying to investigate the impact of digital infrastructure at a very detailed level (municipalities), much more work has to be done to uncover and explain the wide array of effects of highspeed internet.

\section{References}

Ács, Z., Szerb, L., Lloyd, A., 2018. The Global Entrepreneurship Index. The Global Entrepreneurship and Development Institute, Washington, D.C., USA

Akerman, A., Gaarder, I., Mogstad, M., 2015. The Skill Complementarity of Broadband Internet. The Quarterly Journal of Economics, Volume 130(4), pp. 1781-1824

Amt für Statistik Berlin-Brandenburg, 2018. Unternehmensregister Berlin-Brandenburg. Available Online at https://www.statistik-berlin-brandenburg.de/datenbank/inhaltdatenbank.asp, Accessed on May 31, 2020

Armington, C., Ács, Z., 2002. The Determinants of Regional Variation in New Firm Formation. Regional Studies, Volume 36(1), pp. 33-45

Audretsch, D., Dohse, D., Niebuhr, A., 2010. Cultural Diversity and Entrepreneurship: A Regional Analysis for Germany. The Annals of Regional Science, Volume 45(1), pp. 5585

Audretsch, D.B., Lehmann, E.E., Warning, S., 2004. University Spillovers and New Firm Location (No. 0204). Papers on Entrepreneurship, Growth and Public Policy

Bai, Y., 2017. The Faster, the Better? The Impact of Internet Speed on Employment. Information Economics and Policy, Volume 40, pp. 21-25

Bittorf, M., 2013. Germany's Entrepreneurial Culture: Strengths and Weaknesses. Focus on Economics (39)

BMVI, 2014. Bericht zum Breitbandatlas Mitte 2014. Im Auftrag des Bundesministeriums für Verkehr und digitale Infrastruktur (BMVI). (Report to the Broadband Atlas Mid2014. On behalf of the Federal Ministry of Transport and Digital Infrastructure (BMVI)

BMVI, 2018. Aktuelle Breitbandverfügbarkeit in Deutschland, Stand Mitte 2018 (Actual Broadand Avaliability in Germany, State: Mid-2018)

BMVI, 2019a. Bericht zum Breitbandatlas. Teil 1: Ergebnisse 06/2019 (Report to the Broadband Atlas, Part 1: Results 06/2019). Federal Ministry of Transport and Digital Infrastructure: Berlin.

BMVI, 2019b. Breitbandatlas (Broadband Atlas) for Germany. Available Online at: https://www.bmvi.de/DE/Themen/Digitales/Breitbandausbau/BreitbandatlasKarte /start.html, Accessed on May 31, 2020.

Capasso, M., Cefis, E., Frenken, K., 2016. Spatial Differentiation in Industrial Dynamics. The Case of the Netherlands (1994-2005). Tijdschrift voor economische en sociale geografie, Volume 107(3), pp. 316-330

Colombo, M., Croce, A., Grilli, L., 2013. ICT Services and Small Businesses Productivity Gains: An Analysis of the Adoption of Broadband Internet Technology. Information Economics and Policy, Volume 25(3), pp. 171-189 
Cronin, F.J., Parker, E.B., Colleran, E.K., Gold, M.A., 1991. Telecommunications Infrastructure and Economic Growth: An Analysis of Causality. Telecommunications Policy, Volume 15(6), pp. 529-535

David, P.A., 2001. Path Dependence, Its Critics and the Quest for Historical Economics. In: Evolution and Path Dependence in Economic Ideas: Past and Present, 15, p. 40

European Commission, 2010. A Digital Agenda for Europe. Report KOM (2010) 245, Publications Office of the European Union, Brussels

European Commission, 2019a. Connectivity: Broadband Market Developments in the EU: Digital Economy and Society Index Report 2019 - Connectivity. Available Online at: https://ec.europa.eu/digital-single-market/en/broadband-connectivity

European Commission, 2019b. Digital Economy and Society Index (DESI): Germany - 2019 Country Report. Available Online at: https://ec.europa.eu/digital-singlemarket/en/news/digital-economy-and-society-index-desi-2019

European Commission, 2020. Broadband strategy \& policy, 26 March. Available Online at: https://ec.europa.eu/digital-single-market/en/broadband-strategy-policy, Accessed September 30, 2020

Fabritz, N., 2013. The Impact of Broadband on Economic Activity in Rural Areas: Evidence from German Municipalities. Ifo Working Paper No. 166

Fornefeld, M., Delaunay, G., Elixmann, D., 2008. The Impact of Broadband on Growth and Productivity, Comisión Europea (DG Information Society and Media), MICUS

Fritsch, M., Falck, O., 2007. New Business Formation by Industry Over Space and Time: A Multidimensional Analysis. Regional Studies, Volume 41(2), pp. 157-172

Greenstein, S.M., Spiller, P.T., 1995. Modern Telecommunications Infrastructure and Economic Activity: An Empirical Investigation. Industrial and Corporate Change, Volume 4(4), pp. 647-665

Grimes, A., Ren, C., Stevens, P., 2012. The Need for Speed: Impacts of Internet Connectivity on Firm Productivity. Journal of Productivity Analysis, Volume 37(2), pp. 187-201

Hagén, H.-O., Glantz, J., Nilsson, M., 2008. ICT Use, Broadband and Productivity. Yearbook on Productivity, pp. 37-70

Haller, S.A., Lyons, S., 2015. Broadband Adoption and Firm Productivity: Evidence from Irish Manufacturing Firms. Telecommunications Policy, Volume 39(1), pp. 1-13

Hardy, A.P., 1980. The Role of the Telephone in Economic Development. Telecommunications Policy, Volume 4(4), pp. 278-286

Hart, D., Ács, Z., Tracy, S., 2011. High-tech Immigrant Entrepreneurship in the United States. Economic Development Quarterly, Volume 25(2), pp. 116-129

Haynes, K.E., Nijkamp, P., 2006. Infrastructure: The Glue of Megacities. Kenniscentrum Grote Steden

Holl, A., 2004. Transport Infrastructure, Agglomeration Economies, and Firm Birth: Empirical Evidence from Portugal. Journal of Regional Science, Volume 44(4), pp. 693712

IHS Markit, 2018. Broadband Coverage in Europe 2018: Mapping Progress Towards the Coverage Objectives of the Digital Agenda

Jorgenson, D.W., Motohashi, K., 2005. Information Technology and the Japanese Economy. Journal of the Japanese and International Economies, Volume 19(4), pp. 460-481

Kim, Y., Orazem, P.F., 2016. Broadband Internet and New Firm Location Decisions in Rural Areas. American Journal of Agricultural Economics, Volume 99(1), pp. 1-18

Kolko, J., 2010. How Broadband Changes Online and Offline Behaviors. Information Economics and Policy, Volume 22(2), pp. 144-152 
Kolko, J., 2012. Broadband and Local Growth. Journal of Urban Economics, Volume 71(1), pp. 100-113

Kosfeld, R., Mitze, T., 2020. The Role of R\&D-Intensive Clusters for Regional Competitiveness. In: MAGKS Papers on Economics 202001, Philipps-Universität Marburg, Faculty of Business Administration and Economics, Department of Economics (Volkswirtschaftliche Abteilung)

Koutroumpis, P., 2009. The Economic Impact of Broadband on Growth: A Simultaneous Approach. Telecommunications Policy, Volume 33(9), pp. 471-485

Lee, S.Y., Florida, R., Acs, Z., 2004. Creativity and Entrepreneurship: A Regional Analysis of New Firm Formation. Regional studies, Volume 38(8), pp. 879-891

Lehr, W.H., Osorio, C.A., Gillett, S.E., 2006. Measuring Broadbands Economic Impact. Broadband Properties, Volume 24, pp. 12-24

Mack, E., 2014. Businesses and the Need for Speed: The Impact of Broadband Speed on Business Presence. Telematics and Informatics, Volume 31(4), pp. 617-627

Mack, E., Faggian, A., 2013. Productivity and Broadband: The Human Factor. International Regional Science Review, 36(3), pp. 392-423

Mack, E., Grubesic, T., 2009. Broadband Provision and Firm Location in Ohio: An Exploratory Spatial Analysis. Tijdschrift voor economische en sociale geografie, Volume 100(3), pp. 298-315

Matteucci, N., 2014. L'investimento nelle reti NGA a larga banda: la questione settentrionale (Investements into NGA Networks and Broadband: The Northern Question). Economia e politica industriale, Volume 41(4), pp. 129-158

McCoy, D., Lyons, S., Morgenroth, E., Palcic, D., Allen L., 2018. The Impact of Broadband and Other Infrastructure on the Location of New Business Establishments. Journal of Regional Science, Volume 58(3), pp. 509-534

Noseleit, F., 2013. Entrepreneurship, Structural Change, and Economic Growth. Journal of Evolutionary Economics, Volume 23(4), pp. 735-766

OECD, 2003. Broadband Driving Growth: Policy Responses. OECD Publishing

OECD, 2012. OECD Internet Economy Outlook 2012. Organisation for Economic Co-operation and Development

OECD, 2018. Inclusive Entrepreneurship Policies: Country Assessment Notes. Germany 2018

Parajuli, J., Haynes, K., 2017. Spatial Heterogeneity, Broadband, and New Firm Formation. Quality Innovation Prosperity, Volume 21(1), pp. 165-185

Percoco, M., 2016. Highways, Local Economic Structure and Urban Development. Journal of Economic Geography, Volume 16(5), pp. 1035-1054

Qosasi, A., Maulina, E., Purnomo, M., Muftiadi, A., Permana, E., Febrian, F., 2019. The Impact of Information and Communication Technology Capability on the Competitive Advantage of Small Businesses. International Journal of Technology, Volume 10(1), 167-177

Ragnitz, J., 2007. Explaining the East German Productivity Gap: The Role of Human Capital. Kiel Working Papers 1310, Kiel Institute for the World Economy (IfW)

Regionaldatenbank Deutschland, 2018. Unternehmensregister-System (URS). Available Online at: https://www.regionalstatistik.de/genesis/online/code $=52111$, Accessed on May 31, 2020

Roller, L., Waverman, L., 2001. Telecommunications Infrastructure and Economic Development: A Simultaneous Approach. American Economic Review, Volume 91(4), pp. 909-923 
Sarachuk, K., Missler-Behr, M., 2020. ICT, Economic Effects and Business Patterns: A TextMining of Existing Literature. In: Proceedings of the 2020 the $3^{\text {rd }}$ International Conference on Computers in Management and Business, pp. 40-45

Sternberg, R., Bloh, J.v., 2017. Global Entrepreneurship Monitor (GEM): Country Report Germany 2016

Suryanegara, M., Harwahyu, R., Asvial, M., Setiawan, E. A., Kusrini, E., 2019. Information and Communications Technology (ICT) as the Engine of Innovation in the Co-evolution Mechanism. International Journal of Technology, Volume 10(7), pp. 1260-1265

Vassiliou, A., McAleese, M., 2014. Report to the European Commission on New Modes of Learning and Teaching in Higher Education. Luxembourg

Wyrwich, M., Stuetzer, M., Sternberg, R., 2016. Entrepreneurial Role Models, Fear of Failure, and Institutional Approval of Entrepreneurship: A Tale of Two Regions. Small Business Economics, Volume 46(3), pp. 467-492

$\mathrm{Xu}, \mathrm{X} ., \mathrm{Watts}, \mathrm{A} ., \mathrm{Reed}, \mathrm{M} ., 2019$. Does Access to Internet Promote Innovation? A Look at the US Broadband Industry. Growth and Change, Volume 50(4), pp. 1423-1440 